ドラッグデリバリーシステム担体としてのヒト血清アルブミン

異島 優, ${ }^{*}$ 丸山 徹

\title{
Human Serum Albumin as Carrier in Drug Delivery Systems
}

\author{
Yu Ishima* and Toru Maruyama \\ Department of Biopharmaceutics, Graduate School of Pharmaceutical Sciences, Kumamoto \\ University; 5-1 Oe-honmachi, Chuo-ku, Kumamoto 862-0973, Japan.
}

(Received August 5, 2015)

\begin{abstract}
Recently, human serum albumin (HSA) has emerged as a versatile carrier for therapeutic agents against diabetes, cancer, and infectious diseases. Market-approved products include fatty acid derivatives of human insulin for diabetes and the paclitaxel-HSA nanoparticle for various cancers such as metastatic breast cancer and advanced pancreatic cancer. In this review, we focus on the next-generation approach including HSA-binding bioactive gas such as nitric oxide (NO) for treating ischemic/reperfusion injury, cancer, and bacterial infection. To date, pharmacologically active compounds that release NO within the body, such as organic nitrates, have been used as therapeutic agents, but their efficacy is significantly limited by unwanted side effects. Therefore, novel NO donors with better pharmacological and pharmacokinetic properties are highly desirable. The $S$-nitrosothiol fraction in plasma is largely composed of endogenous $S$ nitrosated HSA (SNO-HSA), which is why we are investigating whether this albumin form can be therapeutically useful. Recently, we have developed SNO-HSA analogues such as SNO-HSA with many conjugated SNO groups (polySNO-HSA) prepared using chemical modification. Unexpectedly, we found striking inverse effects between poly-SNOHSA and SNO-HSA. Despite the fact that SNO-HSA inhibits apoptosis, poly-SNO-HSA possesses very strong proapoptotic effects against tumor cells. Furthermore, poly-SNO-HSA can reduce or even completely eliminate the multidrug resistance often developed by cancer cells. In this review, we put forward the possibility that poly-SNO-HSA can be used as a safe, effective multifunctional antitumor agent.
\end{abstract}

Key words — human serum albumin; nitric oxide; drug delivery system; anticancer agent

\section{1.はじめに}

血清中に最も多く含まれる単純タンパク質である ヒト血清アルブミン (human serum albumin; HSA) は，血中や組織間質において血漿膠質浸透圧の維 持・調節，脂肪酸やビリルビンを始めとする内因性 リガンド及び薬物などの外因性リガンドの輸送担 体，抗酸化作用及び酵素的作用（エステラーゼ様作 用）など数多くの機能を有しているマルチ機能タン パク質である. ${ }^{1,2}$ 特に, HSA の血中滞溜性に優れ ている点を利用した融合タンパク質は, 数多く報告 されており，血中半減期の短いタンパク質の滞溜性 の向上にたびたび応用されている (Table 1). ${ }^{3-11)}$

熊本大学薬学部薬剤学分野（干862-0973 熊本市中央区 大江本町 5-1)

*e-mail: y-ishima@kumamoto-u.ac.jp 本総説は, 日本薬学会第 135 年会シンポジウム S08 で 発表した内容を中心に記述したものである.
がん治療における drug delivery system （DDS） に関しては, 1986 年に前田らによって報告された enhanced permeability and retention effect (EPR 効 果) ${ }^{12)}$ の発見の手がかりとなつた腫瘍部位への HSA の高い漏出性と滞溜性からも分かるように，腫瘍部 位への DDS 担体として使用する利点があることは 言うまでもない，腫瘍組織での血管透過性が著しく 克進していることと, リンパ系が発達していないこ とによる高分子や微粒子が血管より流出し易く, 蓄 積し易い現象である EPR 効果は，「受動的ターゲ ティング」の 1 つであり，この理論を基盤に多くの 高分子抗がん剤が承認されていることは周知の事実 である．さらに興味深いことに，HSA を担体とし て使用する利点はこの EPR 効果による「受動的 ターゲティング」だけに留まらない。それは，アル ブミンレセプターと呼ばれる内皮細胞に存在する gp60 や多くの種類のがん組織（主に間質）に存在 
Table 1. Typical Albumin Fusion Partners and Its Potential Therapeutic Applications

\begin{tabular}{|c|c|c|}
\hline Albumin-fusion products & Potential application & Features \\
\hline Albumin-growth hormone (Albutropin ${ }^{\mathrm{TM}}$ ) & Growth hormone deficiency & Clinical trial \\
\hline Albumin-granulocyte colony-stimulating factor (GCSF) & Neutropenia & Clinical trial \\
\hline Albumin-interferon (IFN) - $\alpha 2 \mathrm{~b}$ (Albinterferon $\alpha-2 \mathrm{~b})$ & Chronic hepatitis $\mathrm{C}$ & $\begin{array}{l}\text { Clinical trial } \\
\text { Animal model study }\end{array}$ \\
\hline Albumin-interleukin (IL) -2 (albuleukin) & Malignancy & Clinical trial \\
\hline Albumin-IL-1 receptor antagonist & Rheumatoid arthritis & Animal model study \\
\hline Albumin-glucagon-like pepetide (GLP) 1 (albuglutide) & Diabetes mellitus & Clinical trial \\
\hline $\begin{array}{l}\text { Albumin-atrial natriuretic pepetide (ANP) } \\
\text { Albumin-B-type natriuretic pepetide (BNP) }\end{array}$ & $\begin{array}{l}\text { Hypertension, Congestive heart failure, } \\
\text { Acute myocardial infraction }\end{array}$ & Animal model study \\
\hline $\begin{array}{l}\text { Albumin-tumor necrosis factor (TNF) ligands } \\
\text { Animal model study } \\
\text { (TNF- } \alpha \text {, TWEAK, TRAIL) }\end{array}$ & Malignancy & Animal model study \\
\hline Albumin-thymosin- $\alpha_{1}$ & Hepatitis B and C, Malignancy & Animal model study \\
\hline Albumin-vascular endothelial growth factor (VEGF) $165 \mathrm{~b}$ & Malignancy & Animal model study \\
\hline Albumin-onconase & Malignancy & Animal model study \\
\hline $\begin{array}{l}\text { Albumin-tissue inhibitor of metalloproteinase (TIMP) }-2 \\
{ }^{123} \mathrm{I}-\text { and }{ }^{68} \mathrm{Ga}-\text { labeled cRGD-Alb-TIMP-2 } \\
\text { Tumor imaging probe for SPECT and PET }\end{array}$ & Malignancy & Animal model study \\
\hline Albumin-factor VIIa & Haematophilia A & Animal model study \\
\hline Albumin-coagulation factor IX & Haemophilia B & $\begin{array}{l}\text { Animal model study } \\
\text { Clinical trial }\end{array}$ \\
\hline Albumin domain III-retinol binding protein & Liver fibrosis & Animal model study \\
\hline
\end{tabular}

する secreted protein acidic and rich in cysteine (SPARC) による「能動的ターゲティング」が機能 することである. ${ }^{13-15)}$ このことは，HSA そのもの が，「受動的」だけでなく「能動的」にもがん組織 にターゲティングされていること, その結果, EPR 効果でがん組織まで送達していたものを『腫 瘍間質』へさらには『腫瘍細胞内』にまで能動的に 送達させることが可能であることを示している (Fig. 1)。これらの特性から，アメリカ食品医薬品 局 U.S. Food and Drug Administration (FDA) が 2008 年に『Albumin-based nanoparticles Technology』が DDS 化技術における非常に有用な新しいプ ラットフォームなることを報告しており, ${ }^{16)}$ この技 術を使用したアブラキサンは，米国において 2005 年に乳がん，2012 年 10 月には肺がん，2013 年 9 月 には切除不能な膵臓がんでの承認がなされており, 今後更なる適応拡大が期待されている. Evaluate Pharma の推定では, 2018 年には 17.8 億ドルの売
り上げが予想されていることからも，単にパクリタ キセルの溶解補助剂としての役割だけに留まらない Albumin-based nanoparticles Technology が今後さ らに発展していくだろう。このような背景からも分 かるように，アブラキサン®の開発以降，体内に最 もありふれていた単純タンパク質である HSA は, 新たな DDS キャリアとして世界的に再認識される ようになってきている。，一方，われわれは 40 余年 以上前から HSA の研究を行い, いち早く DDS

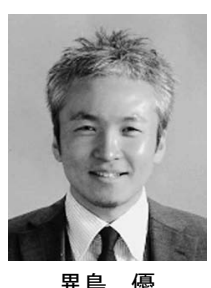

熊本大学薬学部薬剤学分野助教. 2007 年熊本大学大学院薬学教育部博士後期 課程修了, 博士 (薬学). 同年, 同大学 薬学部の医薬高分子学の特任助教, 米 国ピッツバーグ大学医学部・博士研究 員を経て，2011 年より現職. 2015 年よ り, 次世代創薬研究者養成塾顧問を兼 任. 研究キーワード：ドラッグデリバ リーシステム, アルブミン, 一酸化窒 素. 
STEP 1

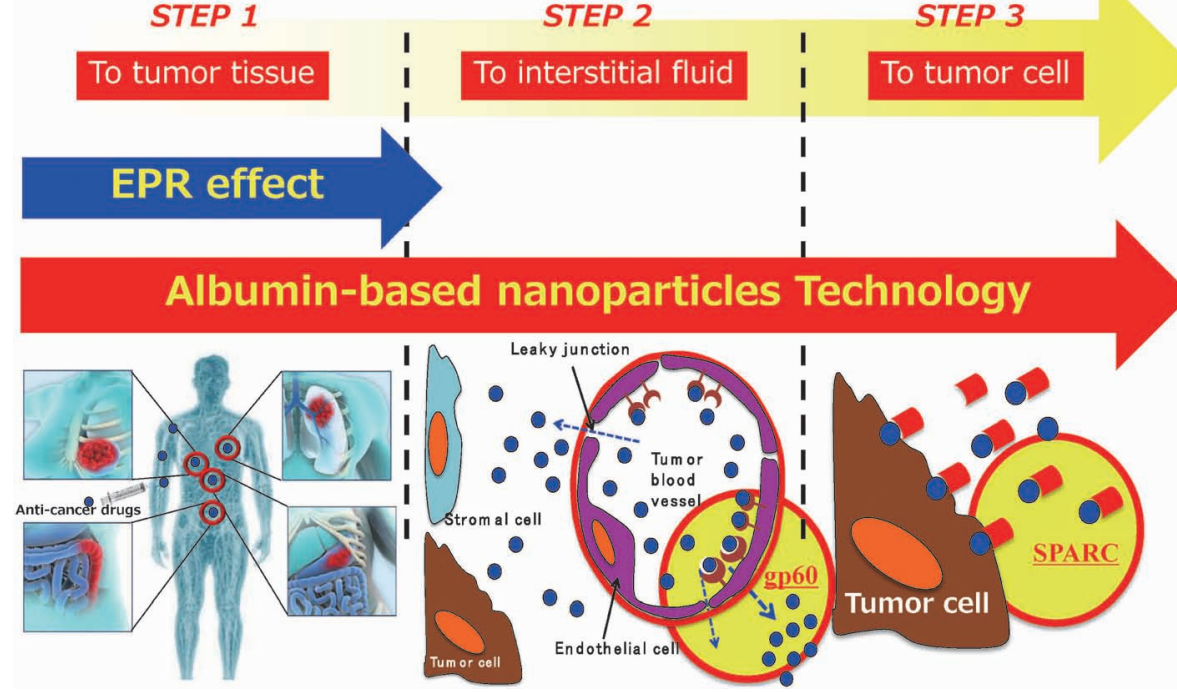

Fig. 1. EPR Effect and Albumin-based Nanoparticles Technology

Uptake of HSA into the tumor interstitium is mediated by the gp60 transcytosis pathway and subsequent binding to secreted protein, acidic and rich in cysteine (SPARC) in the tumor extracellular matrix.

キャリアとして検討を重ねてきた。 その中でも，極 めてユニークかつ制御困難な一酸化窒素（nitric oxide；NO）に着目し，そのデリバリーシステムの 構築と臨床応用への基礎的知見を積み上げてき た. ${ }^{17-22)}$ HSA での NO デリバリーシステムによつ て改善する疾患は多岐に及ぶが，ここではがん治療 への NO の臨床応用に関して，われわれの知見を 概説する.

2. NO 付加ヒト血清アルブミンのがん治療への 応用

2-1. EPR 効果増強剤としての $S$-ニトロソ化 HSA Dimer 上述したように，がん治療におけ る近年のナノ製剤の開発の礎に, 『EPR 効果』は欠 かせない理論となっており，ドキシルをを始め，い くつかのナノ製剤が世界中で承認されている。こう した状況の中, ナノ化による生存率の改善や副作用 の軽減は確かに認められているものの, その反面,

一部のがん種やその腫瘍のサイズ等の違いによって は，無効若しくは効果がそしいことが少しずつであ

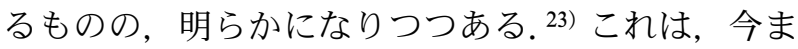
さに，高分子抗がん剤のリバーストランスレーショ ナル・リサーチが待ち望まれている.この原因とし て, 動物実験によって確立されている画一的な担が んモデルでは評価し難いといった EPR 効果の不均 一性の関与が挙げられる。事実, マウス結腸がん由 来の Colon26 細胞とマウスメラノーマ細胞 B16 細
胞では, 内因的な EPR 効果の差が極めて大きいこ と, 加えて, 同一のがん細胞であっても, その腫瘍 の大きさによっても大きく異なることから，腫瘍の 種類や大きさに十分配慮した実験系でのデータの構 築が必要不可欠である。そこでわれわれは，EPR 制御剤を併用することにより，これまでの『内因的 な EPR 効果を単純利用する戦略』から『EPR 効果 を増強・制御する戦略』が可能になるものと考えて いる.このアプローチのメリットは，高分子抗がん 剂に EPR 増強剂を併用投与するだけで, その高分 子抗がん剤の腫瘍内集積性を増大させ，それ以外の 臓器への分布を抑制する結果, 比較的簡便に臨床有 用性を向上させることが期待できる上，汎用性も高 い。この EPR 制御剤として開発したものが，NO を HSA 二量体に存在する 2 力所の Cys-34 位のチ オール基に結合させた $S$-ニトロソ化 HSA Dimer [S-nitrosated-HSA (SNO-HSA) Dimer $]$ である20,24) HSA は二量体化によって, 単量体と比較し, 血中 の半減期が延長し, 腫瘍組織移行性が増大する体内 動態特性を持つ. 加えて, 遺伝子組換え技術を用い た HSA Dimer の作製法により，ミセルやリポソー ムなどにみられる分子サイズの不均一性がなく，高 純度のタンパク質が得られる。この腫瘍選択的な担 体である HSA Dimer に EPR 増強作用を有する NOを付与した SNO-HSA Dimer は, 『Albuminbased nanoparticles Technology』を搭載した魅力的 
な EPR 制御剂になり得る可能性が高い.そこで, この SNO-HSA Dimer の EPR 増強剤としての有用 性に関して, in vivoにて検証した。

\section{2-2. in vivo による SNO-HSA Dimer の EPR 増} 強効果の検討 はじめに, SNO-HSA Dimer の腫 瘍選択的な NO 輸送活性を検証した。担がんモデ ルとして，まずは，血管透過性が高い（内因的 EPR 効果が高い） C26 担がんモデルを作製し， SNO-HSA Dimer を投与したところ，腫瘍でのみ有

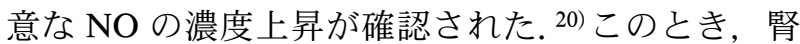
臓や肝臓といつた他の臓器には, NO の濃度変動は 確認されず，低分子の NO ドナーである $S$-二トロ ソグルタチオン (GSNO) の投与では, 腫瘍内の NO 濃度変動も認められなかつた. ${ }^{20)}$ 次に，その腫 瘍に運搬された NOによつて EPR 増強作用が誘導 されるかを，同様の C26 担がんモデルに EPR 効果 の指標であるエバンスブルー法を用いて検討を行つ た. その結果, 約 3 倍の EPR 効果の増強が SNO-

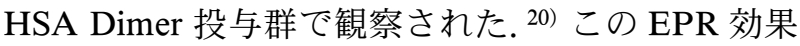
の増強は，SNO-HSA Monomer では比較的小さ かったことから，二量体化による優位性も確認され た.さらに，この SNO-HSA Dimer による EPR 増 強効果を詳細に捉えるべく，EPR 増強時間とその 際の腫瘍内エバンスブルー分布を解析したところ,

EPR 増強効果は SNO-HSA Dimer 投与後 30 以内に ほぼ最大值に達し，その増強作用は 3 時間後まで持 続し，4 時間後には消失した。 また，その際のエバ ンスブルー分布は，血管周囲への分布はもちろん, 血管から遠く離れている腫瘍深部にまで送達してい ることから，SNO-HSA Dimer による EPR 増強効 果は, 腫瘍内全体へ波及していることが明らかと

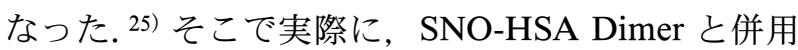
投与した高分子抗がん剂の移行性への影響を評価す ベく，モデル高分子抗がん剂としてドキソルビシン 内包 $\mathrm{PEG}$ リポソームであるドキシルを用いて検 討した。このとき使用した SNO-HSA Dimer の投 与量は, 単独では抗腫瘍効果を認めない量に設定し た。その結果，ドキシルは，EPR 効果を利用した 受動的ターゲティング作用を有するため, ドキシ ル ${ }^{\circledR}$ 単独でもある程度の抗腫瘍効果が確認された が, そのドキシル禅独と比較しても SNO-HSA Dimer 併用群は有意に強力な抗腫瘍効果を示した. さらに，2つの異なる投与量による検討から，ドキ
シル ${ }^{\circledR} の$ 抗腫瘍効果を少なくとも 2,3 倍向上させる

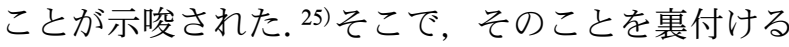
ベく，腫瘍内のドキソルビシン自身の蛍光を定量解 析したところ, ドキソルビシンの腫瘍移行性が 3 倍 程度上昇していた。 その際，肝臓や腎臓などの他臓 器へのドキソルビシンの分布は有意に減少し, 血中 のドキソルビシン量は減少傾向であった。これらの ことから，SNO-HSA Dimer を投与したことによる 腫瘍部位への移行性増大に起因する抗腫瘍効果であ ることが明らかとなつた。ささらに興味深いことに， がん転移に対しても有意に抑制した。これは，転移 病巣部にも引き起こされていることが知られている EPR 効果に対しても，その増強を引き起こしてい ることに起因している可能性が考えられる. 加えて われわれは，血管透過性が低い（内因的 EPR 効果 が低い） B16 担がんモデルでも同様の検討を行い, SNO-HSA Dimer 併用により EPR 増強効果を確認 しており，その移行性増大率は非併用時と比較して 約 6 倍まで上昇したことから，血管透過性が低いが ん種の方がより SNO-HSA Dimer 併用効果が顕著

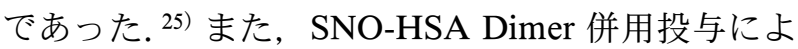
る血圧低下や肝毒性，心毒性などの副作用もなく， 非常に安全性が高いことも確認しているが，ドキシ ル®の手足症候群などの副作用に及ぼす影響は現在 検討中である。以上より，『EPR 効果を増強させた 次世代型 EPR 治療戦略』が SNO-HSA Dimer 併用 により可能になることが示唆された，高分子抗がん 剂の腫瘍移行性を増大することは, 他臓器への分布 量減少（副作用の軽減）や，投与量・回数の減少 （治療費削減ひいては医療経済にも貢献）をもたら すことが予想される. また，SNO-HSA Dimer の作 用は，EPR 増強に基づく高分子抗がん剂の腫瘍移 行性の増大作用であり，このメカニズムは腫瘍周辺 部の血管拡張作用や，腫瘍間質内圧の低下であろ う. ${ }^{25)}$ しかしながら, 腫瘍周辺部の血管拡張は, 酸 素や栄養の供給26)にもつながりかねず，EPR 増強 作用は『諸刃の剣』になり兼ねないため，一過性的 な作用であるべきであろう。実際，SNO-HSA Dimer 投与 4 時間後には EPR 増強作用は認められ なかつた. このことは，SNO-HSA Dimer が不可逆 的ではなく，可逆的な EPR 増強をもたらす EPR 『制御』剂であることを示唆している。これらの知 見は，既に上市されているものや現在開発中の高分 


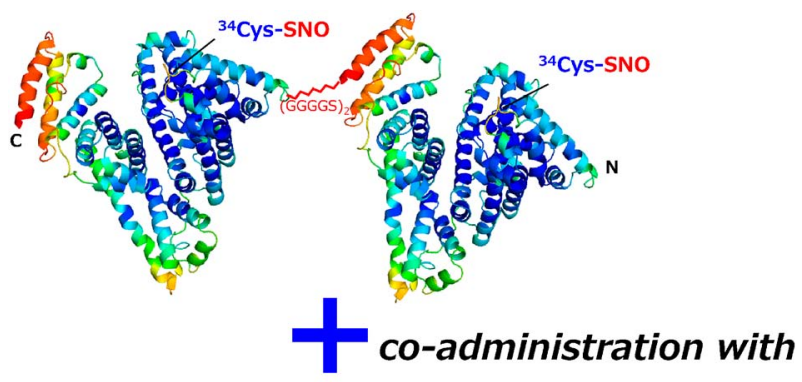

Macromolecular, Anti-tumor Drugs such as Micelles and Liposomes

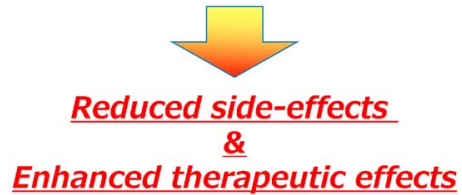

Fig. 2. Novel Nano EPR Enhancer: $S$-Nitrosated Human Serum Albumin Dimer (SNO-HSA Dimer)

子抗がん剂への適応も可能であり, 幅広い様々な高 分子抗がん剂の前投与剂としての可能性が十分期待 される (Fig. 2). ${ }^{20,25)}$

3. がん治療に対する Poly-SNO-HSA の多面的 効果

3-1. 内因的な SNO-HSA と Poly-SNO-HSA の NO 輸送能＼cjkstart近年, NO はアポトーシス誘導やが 几化学療法, 免疫療法, 放射線療法の感受性増強に 関与するなど，多様な抗がん効果を併せ持つことが 明らかとなってきている. ${ }^{22,27,28)}$ そこで新たながん 治療薬として, NO の抗がん剂としての開発が積極 的に展開されている，われわれもまた，NO をがん 細胞へ効率的に輸送できるよう設計された PolySNO-HSA（1 分子の HSA に対し多分子の NO を HSA 表面に化学的に結合させたもの）を作製し, in vitro と in vivo の両面からアポトーシス誘導効果 及び腫瘍増殖抑制作用を持つことを明らかにしてき た. ${ }^{22,29,30)}$ Poly-SNO-HSA は, 主に腫瘍細胞表面に 高発現しているプロテインジスルフィドイソメラー ゼ（protein disulfide isomerase; PDI）を介し，効 率よく細胞内へ NO を供給する. ${ }^{21)}$ その結果, マウ 又結腸がん由来細胞 C26 やラット腹水がん由来細 胞 LY-80, ヒ上慢性骨髄性白血病由来細胞 K562 な ど種差やがん種を問わず，アポトーシスを効率的に 引き起こす. 19,22,29,30) ここで特筆すべきは, PolySNO-HSA が従来の Cys-34 位に SNO 化した SNOHSA とは，相反する生理活性を有する点である

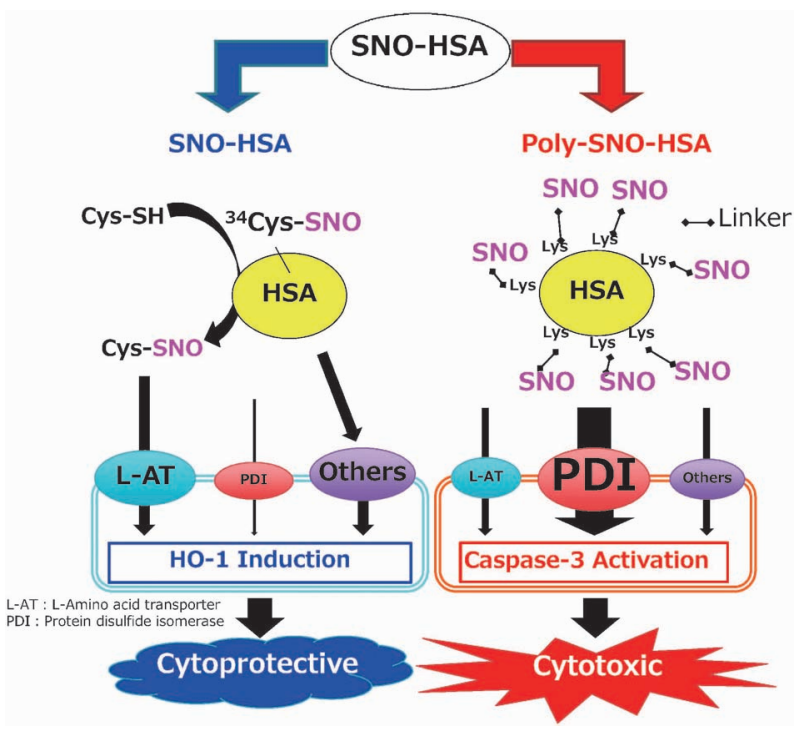

Fig. 3. Differences in the Mechanisms and Consequences of NO Traffic from SNO-HSA and Poly-SNO-HSA to Cells

NO transfer from the SNO group of Cys-34 on SNO-HSA to the cell is partly mediated by the L-amino acid transporter (L-AT) via $S$-transnitrosation to free low molecular weight thiol. By contrast, NO transfer from PolySNO-HSA is mainly mediated by PDI without $S$-transnitrosation to free low molecular weight thiol. The relatively slow transfer of NO from SNO-HSA avoids the presence of high intracellular NO concentrations and leads to cytoprotective activity through HO-1 induction. On the other hand, the NO influx from Poly-SNO-HSA is very fast and pronounced and leads to cell death caused by apoptosis. We used a slightly modified figure to that proposed in Ref. 21).

(Fig. 3). ${ }^{21)}$ 従来の SNO-HSA では，アポトーシス を引き起こすような細胞毒性は，ほとんどみられな い.この生理活性の違いは, NO が効率的に細胞内 に導入できるか否かで制限されており，すなわち， 先述した細胞膜表面の PDI の基質になるか否かで ある。結論から言えば, Poly-SNO-HSA は, 細胞 膜表面の PDI の基質になるのに対し，SNO-HSA は，細胞膜表面の PDI の基質にならない。おそら く, SNO-HSA の SNO 化部位である Cys-34 は, HSA 分子表面から奥まった凹みの部分に位置して いる一方, Poly-SNO-HSA の SNO 化部位は, 表面 に露出していることがこの選択性を見い出している とわれわれは推察している。この偶然の発見とも言 える Poly-SNO-HSA の PDI リガンド能の特性は, NO 供給のターゲティングにも寄与することが分 かってきた。それは, 多くのがん細胞表面の PDI が, 正常細胞の細胞膜表面よりも高発現しているた めである.さらに興味深いことに, 腫瘍細胞が免疫 回避の手段の 1 つとして獲得している MHC class I chain-related gene A (MICA) の分泌に重要なタン パク質として細胞膜上の PDI が着目されている. ${ }^{31)}$ 
本来は多くの細胞の小胞体に多く分布しているはず の PDI が，がん細胞の膜表面に存在するメカニズ ムなど，まだまだ不明な部分が多く残されており， 今後の研究課題の 1 つであると考えている.

3-2.P-糖タンパク質を介した耐性化における

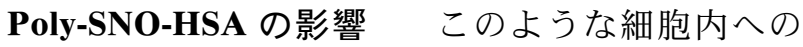
高いNO 供給能を有する Poly-SNO-HSA の活性に 関しては，これまでに興味深い知見がいくつか得ら れた. ${ }^{19)}$ まず，臨床上でも深刻な問題である抗がん 剂多剂耐性の克服に着目した。われわれは，PolySNO-HSA の耐性克服剂としての有用性評価を，ヒ 卜慢性骨髄性白血病由来細胞 K562 のドキソルビシ ン (doxorubicin; $\mathrm{dx})$ 耐性 (K562/dx) 細胞を用い て in vivo と in vitro の実験を行ったところ, PolySNO-HSA と dx を併用処置することで, $\mathrm{dx}$ の抗が ん効果の増強が認められた. ${ }^{19)}$ (Poly-SNO-HSA は, in vivo 実験において腫瘍増殖を抑制させることが 過去の報告で明らかにされているが，この検討では， Poly-SNO-HSA の耐性克服効果に焦点を当てるた め, Poly-SNO-HSA の投与量をあえて減少させ, Poly-SNO-HSA 自身の腫瘍増殖抑制作用が十分に 発揮されない条件にて検討した）また，低酸素誘導 性の hypoxia-inducible factor $1 \alpha \quad(\mathrm{HIF}-1 \alpha)$ を介し たがん細胞の耐性化も報告されているため, 低酸素 条件下にて Poly-SNO-HSA を添加したところ, Poly-SNO-HSA は低酸素による K562 細胞の耐性化

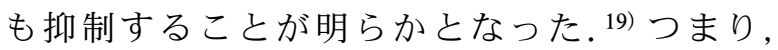
Poly-SNO-HSA は耐性を獲得したがん細胞に対す る感受性増強効果のみならず，がん細胞が而性化し 始める初期段階でも耐性化を予防し，その有用性を 発揮し得ると推察される.

そこで次に，Poly-SNO-HSA による耐性克服メ カニズムの解明を試みた。 NO の作用機序としては, cGMP 経路を介した間接的作用, 及び細胞内夕ン パク質のニトロ化やニトロソ化などの修飾を介した 非䤉素的作用が広く知られており，主にこの 2 つの 経路で種々の生理作用を示すと考えられている. ${ }^{27)}$ そこで, Poly-SNO-HSA の耐性克服作用メカニズ ムとして，これらの経路の寄与を検討した結果， Poly-SNO-HSA は cGMP 経路を介し, 耐性克服作 用を示すことが示唆されたものの, 阻害剂や促進剤 の効果は限定的であり，あくまでもメカニズムの一 部として関与しているものと考えられる。次に,
Poly-SNO-HSA の耐性克服作用に寄与する他の要 因を精査すべく, 耐性獲得の最も代表的な機序であ る抗がん剂の細胞外排出機構に着目した，担がんマ ウスのがん組織並びに細胞を用いて $\mathrm{dx}$ 蓄積量を評 価したところ，Poly-SNO-HSA は，併用投与した $\mathrm{dx}$ の細胞内蓄積量を増加させることが判明した.

すなわち，Poly-SNO-HSA はがん細胞への $\mathrm{dx}$ 蓄積 量を増加させ，抗がん作用を増強させることが示唆 された。そこで，抗がん剂の細胞外排出トランス ポーターとして最も代表的な P-糖タンパク質（Pglycoprotein; P-gp）の発現量の変動を解析した. Western blotting の結果，K562/dx 細胞では P-gp の発現量が顕著に上昇していたが，Poly-SNO-HSA 処理で発現量の低下が認められた。また，P-gpの 発現誘発因子の 1 つに, HIF-1 $\alpha$ の活性化による Pgp 遺伝子の転写活性化が挙げられる。そこで, Poly-SNO-HSA による HIF- $1 \alpha$ の発現変動を Western blotting にて評価した。 K562 細胞を低酸 素環境で 24 時間反応することで HIF-1 $\alpha$ の発現量 は顕著に上昇し, Poly-SNO-HSA 処理で HIF-1 $\alpha$ 発 現量の低下が認められた。 ${ }^{19)} \mathrm{HIF}-1 \alpha$ 発現量の変動 は上述の P-gp の発現量を反映しており，その関連 が強く示唆された。おそらくPoly-SNO-HSA から 放出した NO が HIF-1 $\alpha$ の水酸化酵素を活性化し, HIF-1 $\alpha$ の分解が促進したものと考えられる。この ように Poly-SNO-HSA は HIF-1 $\alpha$ の発現量を低下 させることが判明したことから，P-gpのみなら ず，低酸素微小環境の変化に伴うがんの転移促進, 細胞増殖等, 多様ながんの増悪因子を抑制する可能 性が示唆された. ${ }^{19,24)}$

3-3. オートファジーを介した耐性化における Poly-SNO-HSA の影響＼cjkstart近年では，がん細胞耐 性化におけるオートファジーの関与が多数報告され ており, 32-38) 既に抗がん剤とオートファジー阻害剤 併用の臨床試験が行われていることからも臨床にお けるオートファジー抑制の重要性が窥い知れ る. ${ }^{39-42)}$ 中でも血管新生阻害剂であるべバシズマブ （bevacizumab; Bev）は，低酸素誘導性のオート ファジーを引き起こし, 治療効果が短期かつ限定的 となることや長期の延命効果につながらないことが これまでに報告されている. ${ }^{33-38)}$ しかしながら現在 までに耐性化克服の有効な治療法はなく, 新規治療 薬の開発が切望されている。過去に NO がオート 


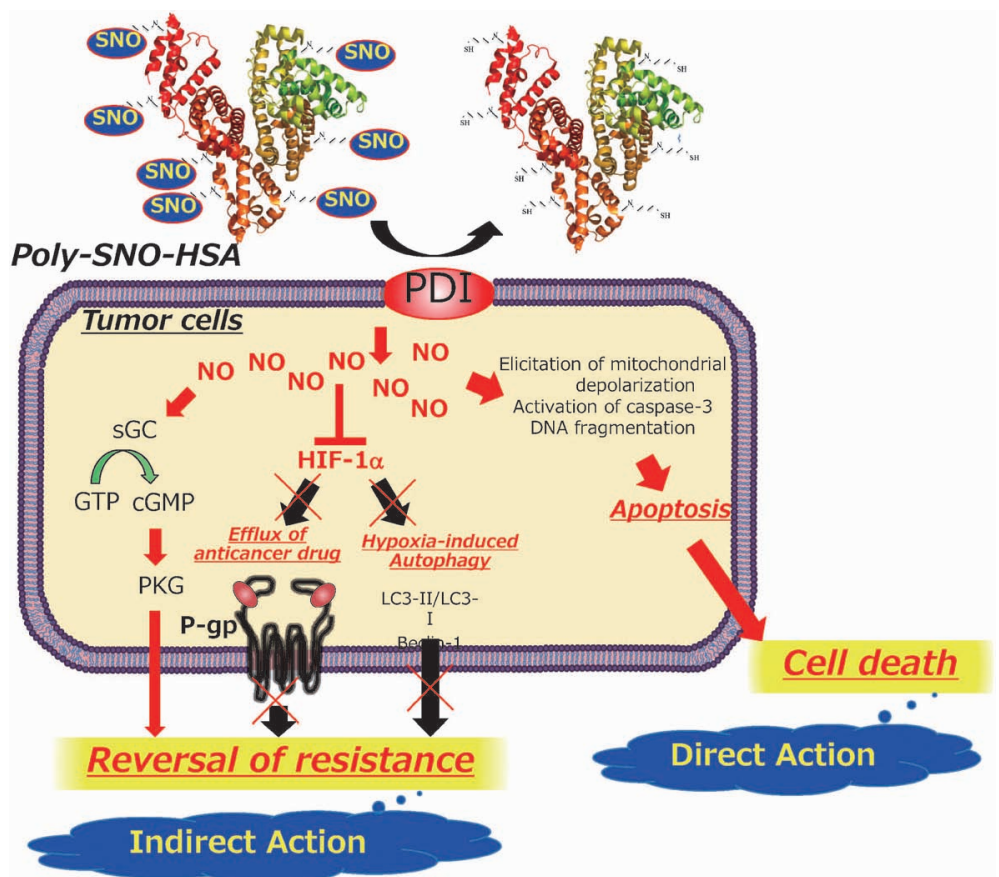

Fig. 4. Mechanisms of Poly-SNO-HSA as a Safe and Strong Multiple Antitumor Agent

Fast and pronounced transfer of NO from Poly-SNO-HSA into the cell mainly takes place via PDI. Within the cell, a high concentration of NO induces apoptosis and reverts dx resistance or hypoxia-induced autophagy by activating a cGMP dependent pathway and HIF-1 $\alpha$. We used a modified figure to that proposed in Ref. 19).

ファジー制御因子であることが in vitro の実験系に て報告されていることから，腫瘍組織への NO デ リバリーシステムさえ構築できれば，がん細胞の オートファジー抑制を介して耐性化克服が期待され る。そこで，腫瘍集積性を持つ HSA に多分子の NO を搭載した Poly-SNO-HSA を用いて，まず,

Poly-SNO-HSA にオートファジー抑制効果がある か否かを, in vitro 実験系にてヒト慢性骨髄性白血 病由来細胞 $\mathrm{K} 562$ 及びマウス大腸がん細胞 C26 を用 いた低酸素誘導性のオートファジーに対して検討し た。その結果, Poly-SNO-HSA は活性型のリン酸 化 JNK 及びその下流の Beclin1 の発現抑制を介し て，オートファジーを抑制することが明らかとなつ た. ${ }^{43)}$ その際の Poly-SNO-HSA の濃度は, アポ トーシスを引き起こす濃度（100 $\mu \mathrm{M}$ 以上）よりも 遥かに低い $1 \mu \mathrm{M}$ 以下であったことから，アポトー シスとは別な機序に基づくものであると推察され た，そこで次に, in vivo 実験系にて C26 担がんマ ウスを用いて Bev の抗腫瘍活性に及ぼす PolySNO-HSA の併用効果を評価した. モデルとして, Bev 繰り返し投与により, オートファジーを引き起 こした C26 細胞担がんマウスモデルを使用した. その結果, Bev と Poly-SNO-HSA の併用投与は,
Bev 単独投与群と比較し, 腫瘍増殖及び肺への転移 を有意に抑制した。このときの腫瘍切片を用いた免 疫染色を行った結果, Poly-SNO-HSA 併用投与が Bevにより促進されたオートファジーを顕著に抑制

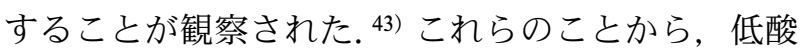
素誘導オートファジーに対しても, Poly-SNO-HSA は, 効果的にオートファジーを抑制し, 低酸素誘導 オートファジーによる耐性化を克服する可能性が示 唆された。

以上の結果を踏まえ, がん治療に対する PolySNO-HSA の多面的効果を要約したものを示す (Fig. 4). ${ }^{19,43)}$ このように, Poly-SNO-HSA は, ア ポトーシス誘導による自身の抗腫瘍効果に加え, 多 剂排出ポンプ阻害作用やオートファジー抑制作用も 併せ持つことから，本知見により多面的な抗腫瘍効 果を有する Poly-SNO-HSA の有効性や有用性がさ らに高まり, 安全かつ効果的な化学療法への応用が 益々期待される.

\section{4. おわりに}

このように, HSA は, NO といった大変重要な 生理活性シグナル分子のキャリアとして, 非常に有 用であることを見い出してきた，現在，われわれは 硫化水素を始め, 更なる生理活性ガスのキャリアと 
しての応用に着手しており，HSA リガンドの選択 肢は非常に多岐に渡るものと考えている，そして何 より HSA は，(1)血中での安定な輸送能や(2)腫瘍へ のターゲィング能, (3)細胞内取り込み能, (4)リガン ドのコントロールドリリース能に至るまで， HSA 本来の性質をそのまま利用することができる極めて 優れた DDS プラットフォームであり，『Albuminbased nanoparticles Technology』は，DDS の領域 で今後益々発展していく分野・技術として, 多いに 期待できると確信している.

謝辞共同研究者である前田 浩教授, 赤池 孝章教授のご助言，ご協力に深謝する.

利益相反＼cjkstart開示すべき利益相反はない.

\section{REFERENCES}

1) Peters T. Jr., "All about Albumin: Biochemistry, Genetics, and Medical Applications," Academic Press, San Diego, 1996.

2) “Human Serum Albumin," ed. by Otagiri M., Chuang V. T., Maruyama T., Kragh-Hansen U., Sojo University Publishing Center, Kumamoto, 2013.

3) Ikuta S., Chuang V. T. G., Ishima Y., Nakajou K., Furukawa M., Watanabe H., Maruyama T., Otagiri M., J. Control. Release, 147, 17-23 (2010).

4) Tomkin G. H., Curr. Opin. Mol. Ther., 11, 579-588 (2009).

5) Huang Y. S., Chen Z., Chen Y. Q., Ma G. C., Shan J. F., Liu W., Zhou L. F., J. Pept. Sci., 14, 588-595 (2008).

6) Subramanian G. M., Fiscella M., LamouséSmith A., Zeuzem S., McHutchison J. G., Nat. Biotechnol., 25, 1411-1419 (2007) .

7) Osborn B. L., Sekut L., Corcoran M., Poortman C., Sturm B., Chen G., Mather D., Lin H. L., Parry T. J., Eur. J. Pharmacol., 456, 149-158 (2002).

8) Duttaroy A., Kanakaraj P., Osborn B. L., Schneider H., Pickeral O. K., Chen C., Zhang G., Kaithamana S., Singh M., Schulingkamp R., Crossan D., Bock J., Kaufman T. E., Reavey P., Carey-Barber M., Krishnan S. R., Garcia A., Murphy K., Siskind J. K., McLean
M. A., Cheng S., Ruben S., Birse C. E., Blondel O., Diabetes, 54, 251-258 (2005).

9) Melder R. J., Osborn B. L., Riccobene T., Kanakaraj P., Wei P., Chen G., Stolow D., Halpern W. G., Migone T. S., Wang Q., Grzegorzewski K. J., Gallant G., Cancer Immunol. Immunother., 54, 535-547 (2005).

10) Sheffield W. P., Mamdani A., Hortelano G., Gataiance S., Eltringham-Smith L., Begbie M. E., Leyva R. A., Liaw P. S., Ofosu F. A., Br. J. Haematol., 126, 565-573 (2004) .

11) Wang W., Ou Y., Shi Y., Pharm. Res., 21, 2105-2111 (2004).

12) Matsumura Y., Maeda H., Cancer Res., 46, 6387-6392 (1986).

13) Elzoghby A. O., Samy W. M., Elgindy N. A., J. Control. Release, 157, 168-182 (2012) .

14) Schnitzer J. E., Oh P., Am. J. Physiol., 263, H1872-H1879 (1992).

15) Li C., Li Y., Gao Y., Wei N., Zhao X., Wang C., Li Y., Xiu X., Cui J., Int. J. Pharm., 468, 15-25 (2014).

16) Hawkins M. J., Soon-Shiong P., Desai N., Adv. Drug Deliv. Rev., 60, 876-885 (2008) .

17) Ishima Y., Fang J., Kragh-Hansen U., Yin H., Liao L., Katayama N., Watanabe H., Kai T., Suenaga A., Maeda H., Otagiri M., Maruyama T., J. Pharm. Sci., 103, 2184-2188 (2014) .

18) Ishima Y., Kragh-Hansen U., Maruyama T., Otagiri M., Biomed. Res. Int., 2013, 353892 (2013).

19) Ishima Y., Hara M., Kragh-Hansen U., Inoue A., Suenaga A., Kai T., Watanabe H., Otagiri M., Maruyama T., J. Control. Release, 164, 1-7 (2012).

20) Ishima Y., Chen D., Fang J., Maeda H., Minomo A., Kragh-Hansen U., Kai T., Maruyama T., Otagiri M., Bioconjug. Chem., 23, 264-271 (2012).

21) Ishima Y., Yoshida F., Kragh-Hansen U., Watanabe K., Katayama N., Nakajou K., Akaike T., Kai T., Maruyama T., Otagiri M., Free Radic. Res., 45, 1196-1206 (2011).

22) Katayama N., Nakajou K., Ishima Y., Ikuta S., Yokoe J., Yoshida F., Suenaga A., Maruyama T., Kai T., Otagiri M., Nitric Oxide, 22, 259-265 (2010).

23) Prabhakar U., Maeda H., Jain R. K., SevickMuraca E. M., Zamboni W., Farokhzad O. 
C., Barry S. T., Gabizon A., Grodzinski P., Blakey D. C., Cancer Res., 73, 2412-2417 (2013).

24) Ishima Y., Fang J., Kragh-Hansen U., Yin H., Liao L., Katayama N., Watanabe H., Kai T., Suenaga A., Maeda H., Otagiri M., Maruyama T., J. Pharm. Sci., 103, 2184-2188 (2014) .

25) Kinoshita R., Ishima Y., Ikeda M., KraghHansen U., Fang J., Nakamura H., Chuang V. T. G., Tanaka R., Maeda H., Kodama A., Watanabe H., Maeda H., Otagiri M., Maruyam T., J. Control. Release, 217, 1-9 (2015) .

26) Kamphorst J. J., Nofal M., Commisso C., Hackett S. R., Lu W., Grabocka E., Vander Heiden M. G., Miller G., Drebin J. A., BarSagi D., Thompson C. B., Rabinowitz J. D., Cancer Res., 75, 544-553 (2015).

27) Stuehr D. J., Gross S. S., Sakuma I., Levi R., Nathan C. F., J. Exp. Med., 169, 1011-1020 (1989).

28) Laval F., Wink D., Carcinogenesis, 15, 443447 (1994).

29) Katayama N., Nakajou K., Ishima Y., Ikuta S., Yokoe J., Yoshida F., Suenaga A., Maruyama T., Kai T., Otagiri M., Nitric Oxide, 22, 259-265 (2010).

30) Katayama N., Nakajou K., Komori H., Uchida K., Yokoe J., Yasui N., Yamamoto H., Kai T., Sato M., Nakagawa T., Takeya M., Maruyama T., Otagiri M., J. Pharmacol. Exp. Ther., 325, 69-76 (2008).

31) Kaiser B. K., Yim D., Chow I. T., Gonzalez S., Dai Z., Mann H. H., Strong R. K., Groh V., Spies T., Nature, 447, 482-486 (2007).

32) Sarkar S., Korolchuk V. I., Renna M., Imarisio S., Fleming A., Williams A., Garcia-Arencibia M., Rose C., Luo S., Underwood B. R., Kroemer G., O’Kane C. J., Rubinsztein D. C.,
Mol. Cell, 43, 19-32 (2011).

33) Vredenburgh J. J., Desjardins A., Herndon J. E. 2nd, Dowell J. M., Reardon D. A., Quinn J. A., Rich J. N., Sathornsumetee S., Gururangan S., Wagner M., Bigner D. D., Friedman A. H., Friedman H. S., Clin. Cancer Res., 13, 1253-1259 (2007).

34) Bergers G., Hanahan D., Nat. Rev. Cancer, 8, 592-603 (2008).

35) Jain R. K., Oncology (Williston Park), 19, 716 (2005).

36) Saltz L. B., Lenz H. J., Kindler H. L., Hochster H. S., Wadler S., Hoff P. M., Kemeny N. E., Hollywood E. M., Gonen M., Quinones M., Morse M., Chen H. X., J. Clin. Oncol., 25, 4557-4561 (2007).

37) Shojaei F., Ferrara N., Cancer J., 13, 345-348 (2007).

38) Kindler H. L., Niedzwiecki D., Hollis D., Sutherland S., Schrag D., Hurwitz H., Innocenti F., Mulcahy M. F., O'Reilly E., Wozniak T. F., Picus J., Bhargava P., Mayer R. J., Schilsky R. L., Goldberg R. M., J. Clin. Oncol., 28, 3617-3622 (2010).

39) Selvakumaran M., Amaravadi R. K., Vasilevskaya I. A., O’Dwyer P. J., Clin. Cancer Res., 19, 2995-3007 (2013).

40) Augustine M. K., Choi M. D., Stefan W., Beth Levine M. D., N. Engl. J. Med., 368, 651-662 (2013).

41) Hu Y. L., DeLay M., Jahangiri A., Molinaro A. M., Rose S. D., Carbonell W. S., Aghi M. K., Cancer Res., 72, 1773-1783 (2012).

42) Mathew R., Karantza-Wadsworth V., White E., Nat. Rev. Cancer, 7, 961-967 (2007).

43) Ishima Y., Inoue A., Fang J., Kinoshita R., Ikeda M., Watanabe H., Maeda H., Otagiri M., Maruyama T., Cancer Sci., 106, 194-200 (2015) . 